\title{
Gara Garayev'in piyano eserlerinde Doğu-Batı bağlamında uygulanan muğam ilkeleri
}

\section{Sevil Mikayılova*}

Sorumlu Yazar:

*Müzik Koleji, Müzikoloji Bölümü öğretmeni, Bakü, Azerbaycan

Email: seva.m.s@mail.ru, https://orcid.org/0000-0001-9155-8517

\begin{abstract}
Özet
Azerbaycanlı bestecilerin piyano yaratıcılığının çeșitli gelișim așamalarında, yeni sanat akımlarına sürekli bir ilgi, müzikal ifade araçlarını yenileme eğilimi var. Yirminci yüzyılın ilk yarısında, Romantizm ve Empresyonizm ile birlikte, muğamdan gelen ilkeleri de içeren Azerbaycan piyano müziğinin milli gelenekleri Avrupalı bestecilerin çalıșmalarına dahil edilmiștir. Bunlardan biri, G.Garayev'in adıyla bağlantılı olan ve daha sonra ulusal besteci yaratıcılığının diğer alanlarında parlak tezahürünü bulan neoklasizm eğilimiydi. Azerbaycan bestecilerin piyano çalıșmalarında neoklasizmin eğiliminden bahsederken, bu üslubu karakterize eden ana özelliklerden kısaca bahsetmemiz gerekiyor. G.Garayev'in piyano için yaptığı çalıșmalar örneğinde, ulusal müzikal düșüncenin ilkelerinin neoklasik tarzda kullanılan araçlarla birleștirildiğini görüyoruz. Bestecinin çok sesli eserlerinde, muğam düșüncenin düzenlilikleri artık geçmișin ve günümüzün çok sesli yazım üslubuyla aynı değildir, aynı zamanda on iki tonlu kromatik tonalitenin "ortamında" da tezahür eden bu son derece farklı sistemlerin kesișme noktasını bulmada yazarın elde ettiği yeni sanatsal kalitenin açık bir örneği olarak kabul edilir.
\end{abstract}

\section{Anahtar kelimeler}

gara garayev, besteci, piyano, doğu-batı, müzik, çalıșma, analiz

Azerbaycan bestekarlarının fortepiano yaradıcılığının müxtelif inkișaf merhelelerinde daim yeni bedii cereyanlara maraq, musiqi ifade vasitelerinin yenileșdirilmesine meyil müșahide edilmișdir. XX esrin birinci yarisinda Azerbaycan fortepiano musiqisindemillienenelerveocümleden muğamdan axıb gelen prinsipler romantizm ve impressionizm ile yanașı, Avropa bestekar yaradıcılığında yer almıș bezi bașqa üslub temayülleri mecrasında da reallașdırılırdı. Bunlardan biri Q.Qarayevin adı ile bağlı olan ve sonradan milli bestekar yaradıcılığının diger sahelerinde de parlaq tezahürünü tapan neoklassisizm temayülü idi (Qafarova, 1992, s.26). Azerbaycan bestekarlarının fortepiano yaradıcılığında neoklassisizm temayülünden danıșarken bu üslubu seciyyelendiren başlıca xüsusiyyetleri qısa șekilde qeyd etmeyi lazım bilirik.

Neolkassisist üsluba maraq fortepiano eserlerinde fakturanın polifonikleșdirilmesinde, «qrafik» ifade üsulunda, ciddi klassik formalara müracietde, rasionalist aydın tefekkür terzinde özünü büruze verir. Melumdur $\mathrm{ki}$, neoklassisizm bir cereyan kimi 1920-ci ilde F.Buzoninin F.Bekkere açıq mektub șeklinde çap etdirdiyi «Yeni klassisizm» adlı meqalede 
«elan edilmiș» ve «XVII -XVIII esrlerin qedim reqs musiqisine müraciet, qedim senetkarların polifionik yazı üsullarının dirçeldilmesi, opera-buffa janrının heyata qaytarılması, erken klassisizm üçün seciyyevi olan janrlara müraciet» kimi müeyyen edilmișdi. 1924-cü ilde İ.Stravinskinin ireli sürdüyü «Geriye, Baxa doğru» șüarı da müxtelif milli bestekarlıq mekteblerini temsil eden bir sıra senetkarlar terefinden desteklenir. Bu çağırıșın mahiyyeti İ.S.Bax musiqisi üçün seciyyevi olan mentiqin, inkișaf ve musiqi forması qurulması prinsipleri ile en yeni ifade vasitelerinin birleșdirilmesinden ibaret idi. Neoklassisizm, stilizasiyadan tamamile ferqli olan bir temayül idi, bele $\mathrm{ki}$, eger stilizasiya, yeni üslublașdırma bestekarın öz üslubunu başqasınınkına tabe etdirmesi demek idise, neoklassisizm bunun eksine olan bir temayül olaraq, bașqasının üslubunu bestekarın öz üslubuna tabe etdirmesi ile seciyyelenirdi. Bir sira fortepiano eserlerinde neoklassisist mövqeden çıxıș eden Q.Qarayevin dest-xettinde bu, tamamile aydın tezahür edir (ibrahimova, 2011, s.44).

\section{Q.Qarayevin neoklassisist üsluba} müracieti onun bütün yaradıcılığı boyu müșahide edilen senet axtarıșları ile, bestekarın müxtelif üslubların seciyyevi cehetlerini milli zeminde sinamaq niyyyetiile bağlı idi ve șübhesiz ki, bu marağın oyanmasında onun XX esr musiqisinin korifey senetkarlarının musiqisi ile tanışlığı da mühüm rol oynamıșdı. Bir terefden P.Hindemit, i.Stravinski yaradıcılığı ile yaxın tanışlıq, bununla yanașı, D.Şostakoviç, S.Prokofyev musiqisine olan hedsiz maraq bunu șertlendirmișdi. Tesadüfi deyil ki, Q.Qarayevin qeleminden çıxmış, neoklassisizm üslubuna müracietin parlaq nümunesi olan Sonatina onun D.Şostakoviçin sinfinde tehsil aldığı dövrde yazılmıșdır.

Q.Qarayevin neolkassisist üsluba aid olan fortepiano eserlerinde bu temayül üçün seciyyevi olan bașlıca elametleri görürük ki, bunlar erken klassisizm dövrü janr ve formalarının dirçeldilmesinde, qedim musiqiye xas cehetlerin XX esrin kompozisiya vasiteleri ile zenginleșdirilmesinde, qedim musiqide tetbiq edilen üsulların XX esr musiqisinin janr, forma, dil ünsürleri ile qovușdurulmasında özünü büruze verir. Q.Qarayev yaradıcılığında yer almış neoklassisizmin orijinallığ ondadır ki, XX esr musiqisinde geniș intișar tapmıș bu üslub temayülünün seciyyevi elametleri burada milli musiqi tefekkürünün ve ilk növbede muğam senetinin mühüm üslub cehetleri ile üzvi sintezini tapmıșdır. Q.Qarayevin neoklassisist üslubda yazdığı fortepiano eserlerinde muğamdan gelen prinsipler materialın teșkili, musiqi forması, faktura ve xüsusen, melos seviyyesinde tamamile aşkar nezere çarpır.

Milli musiqi enenesinin neoklassisizm üslubu mecrasında en parlaq tecessümü nümunelerinden biri Q.Qarayevin a moll Sonatinasıdır. Yuxarıda qeyd etdiyimiz kimi, bestekar bu eseri Moskva konservatoriyasında D.Şostakoviçin sinfinde tehsil aldığ dövrde (1943) bilavasite öz müelliminin rehberliyi altında yazmıșdır. Bu eser cavan bestekarın neoklassisist yazı üslubunun xüsusiyyetlerini muğam ve așıq senetinden gelen prinsiplerle uzlașdırmaq istiqametinde apardığ yaradıcılıq ișinin bariz nümunesi hesab edile biler. 
Qeydedekki, herbir senet eserindeolduğu kimi, bu Sonatinada da müxtelif üslub ve cereyanlardan ireli gelen xüsusiyyetler müellifin ferdi qelemi, benzersiz destxetti çerçivesinde o derecede möhkem ve üzvi bir qovușuq șeklinde tecessümünü tapmıșdır ki, bunları bir-birinden süni suretde ayıraraq tehlil etmek mümkün deyildir. Lakin dissertasiyada qarşıya qoyduğumuz vezifelerle bağlı olaraq, tehlil prosesinde bestekarın ferdi destxettini formalașdıran başlıca ünsürleri ayrılıqda diqqete çatdırmağı vacib hesab edirik.

Sonatinanın hisselerinden her birinde ümumi neoklassisist üslub mecrasında kökleri muğama gedib çıxan prinsiplerin musiqi toxumasının müxtelif seviyyelerinde özünü büruze verdiyini göre bilerik. Bele ki, Sonatinanın birinci hissesinde ilk növbede diqqeti tematizmin «prokofyevsayağı» yüngül motorikası ile seçilen hereketi celb edirse, mövzunun açılıșı prosesinde meqam-lad baxımından buradakı șur intonasiyaları («h» ve «b» tonlarının «oyunu» «a» mayeli șura ișaredir) getdikce möhkemlenerek, inkişaf prosesinde gah melodiya ile bas arasında, gah fakturanın eyni bölümünde «h» ve «b» tonlarının növbeleșmesi sayesinde eyniadlı muğamın instrumental versiyası ile konkret assosiasiyalar doğurur.

Sonatinanın birinci hissesinde struktur qaydalarına ciddi riayet edilmesi, tematizmin inkișaf üsulları klassisizm dövrü musiqisine xas olan cehetler kimi qavranılır. Melodiyadakı xromatizmler ümumi seslenmeye dissonanst boyalar așılasa da, musiqinin bașlıca «șur» abhavası danılmazdır ve tamamile aydın özünü büruze vermiș olur. Burada meqam tezadları da maraqlı șekilde qurulur, bele $\mathrm{ki}$, müeyyen mesafede mövzulararasındakı kontrast «a» ve «h» mayeli șur meqamalarının qarșıladırılması șeklinde tefsir edilir; birinci hissenin son bölmesinde her ikisinin esas tonallıq rolunu oynayan aşurda seslenmesi sonata dramaturgiyasının esas prinsipine uyğun (tezad ve bunun inkişaf neticesinde yeni keyfiyyet kesb etmesi) hell edilmişdir. Birinci hissedeki intonasiya inkişafı prosesinde dissonansl seslenmeler fonunda çox zaman meqam mensubluğu «itib-batan», perdelenen tematizmin hissenin son xanelerinde «a» mayeli șur meqamının seciyyevi ve temiz kadans intonasiyası ile tamamlanması olduqca elametdardır ve çox zaman mehz bu șekilde tamamlanan așıq havalarının sonluğunu xatırladır.

Sonatinanın ikinci hissesinde muğamdan gelen prinsipler ilk növbede hissenin tematizminin teqdimatı ve inkișafı prosesinde, hemçinin intonasiya inkişafının dramaturgiyasında öz eksini tapmıșdır. $\quad \mathrm{Bu}$ hissede mövzunun teșekkülü ve inkişafı bilavasite muğam kompozisiyasında mövzu amilinin teqdimatı ve inkişafı prinsipi ile bağlıdır. $\mathrm{Bu}$ mülahizeye aydınlıq getirmek üçün muğamın özünde mövzu mefhumunun xüsusiyyetleri ve bunun kompozisiyada teqdimat ve inkişaf xüsusiyyetleri barede müeyyen tesevvüre malik olma zeruridir. «Muğamın ferdi özelliyi ilk növbede buradakı kiçik tematik özek - mikromövzudadır... Muğamın en kiçik bitkin qurumu - gușe hemin mikromövzunun defelerle variant yolu ile deyișdirilmesi neticesinde bundan cücerib yetişir" (Babayev, 1990, s.34). "Destgahların tehlili muğamda müstesna formayaradıcı ve dramaturji ehemiyyete malik olan xüsusi tipli musiqi mövzusunun olduğunu iddia etmeye 
esas verir... Muğamdakı Maye mefhumu burada bașlıca mövzu funksiyasını yerine yetirir ki, bu da bütöv kompozisiyada total teșkiledici ehemiyyete malikdir. Muğam monodiyasındakı bütün inkișaf prosesi muğamın esas qayesini özünde cemleșdiren bu «cövher»den, «maya»dan töreyir» (Mahmudova, 1994, s.88).

Muğam mövzusunun teșekkülü ve inkișaf prinsipini açıqlayan bu müddeaları esas götürsek, deye bilerik ki, Q.Qarayevin fortepiano üçün Sonatinasının ikinci hissesinde mövzunun teqdimatı mehz bu prinsipe esaslanır. Burada mövzu cüzi bir motivden töreyerek, tedricen genișlenir, meqam perdeleri etrafında dolanmalar, kiçicik intonasiya vahidlerinin variantlı «açıqlanması», sekvensiyavari hereket (çox vaxt aşağı istiqametde) vasitesile get-gede öz diapazonunu genișlendiren bir melodiyaya çevrilir. prosesinde aşkara çıxaraq, kulminasiya anında son derece ifadeli ve tesirli șekilde teqdim edilir. Hisseni bașlayan bu cüzi material Sonatinanın bütün ikinci hissesinde tematizmin «maya»sını teșkil edir ki, bele bir inkișaf da, yuxarıda qeyd etdiyimiz kimi, mehz muğam kompozisiyaları üçün olduqca seciyyevidir. Mövzu, növbe ile «a», daha sonra «f» ve repriz bölmesinde yeniden «a» mayeli șurda keçir. Hisse boyu baș veren inkișaf, yükselen xett üzre aramla davam eden bir proses kimi gedir ve bu prosesin gedișinde mövzunun tedricen genișlenmesi ile beraber, faktura cehetden de «kreșșendovari» bir inkișafı müșahide edirik, bele ki, faktura get-gede yeni seslerin daxil olmasi hesabına polifonikleșmeye bașlayır. Hem diapazionun davamlı ve ardicıl suretde genișlenmesi, hem fakturanın getdikce qatılașması, ümumi dinamikanın
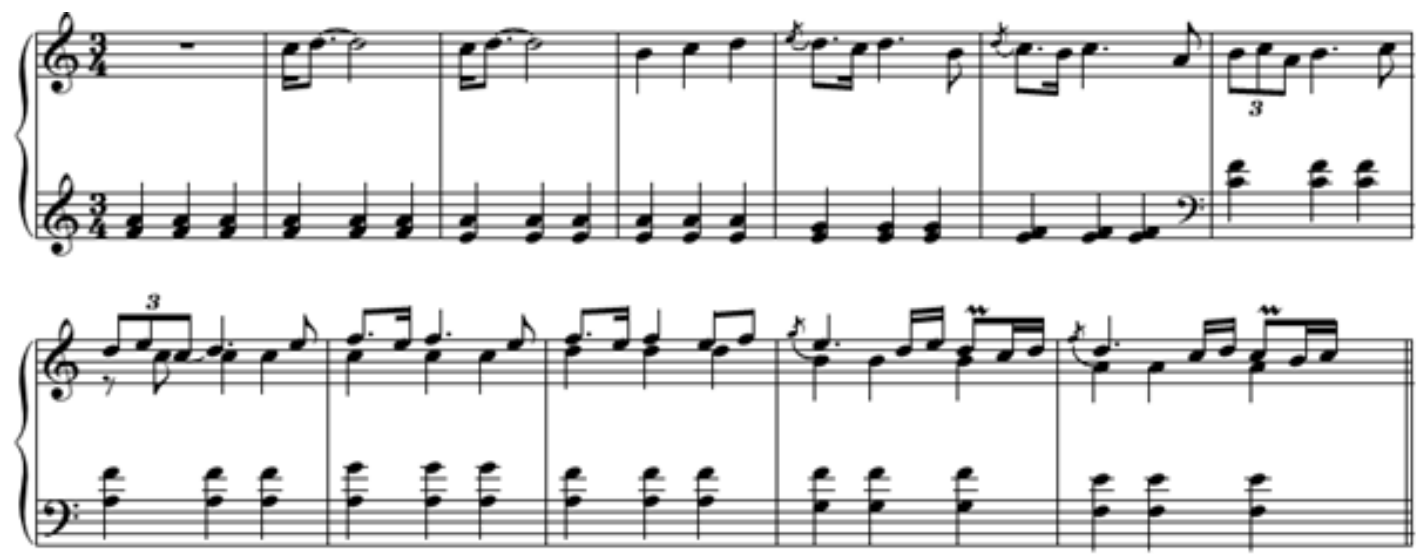

Nota 1: Qara Qarayev fortepiano üçün Sonatina II hisse

Kiçik bir tematik özekden bütöv kompozisiyanın tematizminin töremesi - bilavasite muğam kompozisiyalarını seciyyelendiren prinsipdir ki, Sonatinada bunun parlaq tecessümünü görürük. Sonatinanın bu hissesinin evvelinde verilen hemin cüzi intonasiya nüvesinin ehemiyyeti hisse boyu sonrakı inkişaf yükseliși seslenme gerginliyinin de tedricen artmasını şertlendirir; reprizde mövzunun basda ve melodiyada iki müxtelif tonallıqda keçirilmesi zamanı tetbiq edilmiş stretta üsulu sayesinde politonal effekt meydana gelir; hissenin kulminasiya meqamında bașlıca mövzunun özeyini teșkil eden intonasiya 
elementi en yüksek registrde tekidle ve son derece ekspressiv seslendikden sonra qisa bir eniș baș verir ki, bu zaman hemin intonasiya nüvesinin basda esas tonallıqda seslendiyini görürük. Bu, hissenin kodasıdır. tamamile yeni müstevide tetbiq edildiyinin șahidi oluruq.

Qeyd edek ki, bu hissede inkişaf prosesinde mövzunun muğam tematizminin inkişafı üçün seciyyevi
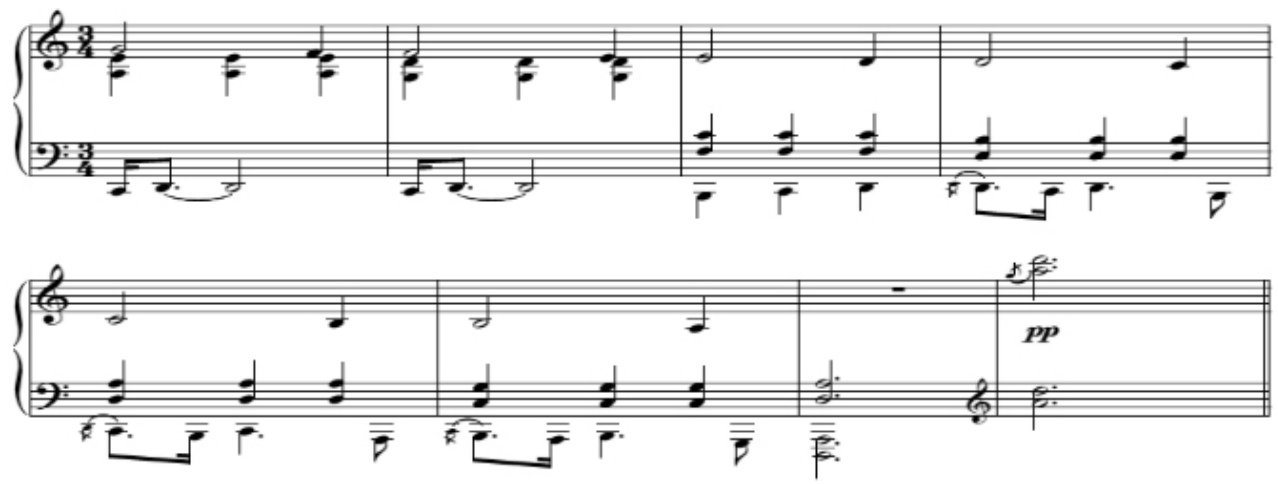

Nota 2: Qara Qarayev fortepiano üçün Sonatina II hisse koda

Belelikle, Sonatinanın ikinci hissesi boyu aramla davam eden pillevari yükseliș ve ani, olduqca qisa bir enişle evvelki nöqteye qayıdılmasını da bilavasite muğam kompozisiyasının qurulușunu seciyyelendiren prinsip ile elaqelendire bilerik. Sonatinanın ikinci hissesinde bașlıca qayenin, fikrin tematik ifadesi olan bașlanğıc intonasiyasını muğam kompozisiyasının evvelinde «beyan edilen» esas qayeni ifade eden mözvu ile müqayise ede bilerik; her iki mövzunun teșekkülü ve inkișaf prosesi de eyni isiqametde - yükselen xetle inkișafa meruz qalır. Muğamda bu esas mövzu ilk defe «Berdașt» şöbesinde teqdim edilerek sonradan muğam şöbeleri ile pille-pille yükselir ve kulminasiya nöqtesine çatdıqdan sonra baș veren lakonik eniş vasitesile yeniden qayıdıb özünün evvelki çıxıș nöqtesinde bir daha tesdiqlenir. Bu baxımdan Sonatinanın ikinci hissesinde bestekar terefinden muğam kompozisiyasının ve formaprosesinin esasında duran prinsipin olan üsullarla, intonasiya özeklerinin tekrarı ve variantlanması, sekvensiyavari hereket vasitesile açılması, ümumiyyetle Q.Qarayev melosuna xas olan cehetdir. Buna bestekarın tekce fortepiano yaradıcılığından deyil, diger janrlarda yaratdığı eserlerinden de çoxlu sayda misallar getire bilerik. Meselen, «Leyli ve Mecnun» simfonik poemasında kömekçi partiyanın mövzusu, «Don Kixot» simfonik qravürlerinden «Aldonsa» ve «Don Kixotun ölümü» ve bir sıra bașqa nümuneler Q.Qarayev melosunun köklerinin bilavasite muğam zemininde formalașdığını gösterir. Yeni bu xüsusiyyet ümumilikde Q.Qarayevin ferdi dest-xettinin vacib bir ünsürü ve bunun muğamla bağlılığının bariz nümunesi kimi qiymetlendirilmelidir.

Eyni zamanda, Sonatinanın bu hissesinde tematizmin teșekkülü ve inkișaf prinsipleri bestekarın neoklassisist üsluba müracietinin de bariz nümunesini teșkil edir. Bele ki, burada dahi alman 
senetkarı i.S.Baxın musiqisinde rast gelinen tematik inkișaf üsulları ile de müqayise apara bilerik.

Q.Qarayevin I.S.Bax yaradıcılığına maraq göstermesi, bir terefden polifoniyaya meylli olması, eyni zamanda öz eserlerinde tematizmin qurulușu prinsiplerinde alman bestekarının destxetti üçün seciyyevi olan xüsusiyyetlere arxalanması tesadüfi deyildir. İlk növbede qeyd edilmelidir ki, dahi Üzeyir bey enenelerinin davamçısı olan Q.Qarayev, milli musiqi tefekkürü prinsiplerini özünde dașiyan bir senetkar kimi hem alman bestekarının dest-xetti, hem de milli musiqimiz üçün ortaq hesab edile bilen intonasiya ifade vasiteleri ve inkișaf üsullarının mövcudluğunu sezerek bunları üze çıxarmağa çalıșırdı. i.S.Baxın eserleri üçün olduqca seciyyevi olan cehet - eserin esas ideyasının «maddileșdirilmiş» ifadesi olan, evvelde tezis șeklinde teqdim edilen kiçik bir intonasiya materialından bütöv eserin tematizminin meydana gelmesi, bu mövzunun öz daxili potensialını tedricen açıqlaması prosesinde sanki fasilesiz davam eden bir intonasiya axınının yaranması, serbest metrik qurulușa malik olan mövzuların inkişafında diqqeti celb eden improvizasiyalılığın geniş yer alması, ümumiyyetle, eserin başlica mövzusunun merhele-merhele davam eden inkișafı - bütün bunlar Azerbaycan muğam kompozisiyasında da rast geldiyimiz cehetlerdir. Aydındır ki, i.S.Bax musiqisinin tamamile ferqli bir bedii-estetik platformaya esaslandığını, tamamile ferqli bir milli ve professional zeminde, ferqli üslub mecrasında yetișdiyini nezere aldıqda, bu müqayise qeribe görüne biler. Lakin bestekarın öz eserlerinde tetbiq etdiyi prinsipler eyni zamanda musiqi tefekkürüne aid en ümumi tefekkür qanunlarından ireli geldiyine göre hemin qanunların dövrden, milli mensubiyyetden asıl olmayaraq, ümumiyyetle, musiqi yaradıcılığı üçün seciyyevi olduğunu nezere alaraq, müxtelif medeniyyetler daxilinde özünü göstermesini qanunauyğun hesab ede bilerik. Q.Qarayevin eserleri bunun bariz nümunesidir. Q.Qarayev özünün fortepiano eserlerinde Bax musiqisi üçün seciyyevi olan reçitativdeklamasiya düzümlü melos ile muğam melosunun xüsusiyyetlerini üzvi suretde birleșdirmeye nail olmuş ve bu sintez bestekarın ferdi dest-xetti ve üslubu kontekstinde yeni bedii keyfiyyet kesb etmișdir.

Sonatinanın üçüncü hissesi rondo formasında yazılmıșdır ve ilk baxıșda burada tematik rengarengliyin olması teessüratı yaranır. Bele ki, refren funksiyasını daşıyan mövzu - bas sesde «staccato»larla verilmiș sade müșayietin fonunda seslenen, düzülüşü etibarile S.Prokofyevin qeribe bir yüngüllüye malik olan skertsovari melodiyaların xatırladan, eyni zamanda așkar suretde yallı ritmikasının xüsusiyyetleri ile seçilen mövzudur; epizodlar ise bundan hem faktura cehetden, hem obrazlıemosional baxımdan ferqli olub, akkord qurulușa malik, lirik mövzulardır. Lakin eslinde bu, yalnız ilk teessüratdır ve üçüncü hisseni diqqetle nezerden keçirsek, burada da möhkem bir tematik qohumluğun olduğunu görerik. $\mathrm{Bu}$ hissenin ilk baxișda rengarenglik teessüratı bağıșlayan tematizmi eslinde eyni bir intonasiya ehtiyatından töremișdir. Refren ve epizodların melodik xetlerini müqayise etmekle bunun șahidi oluruq:

Belelikle, Q.Qarayevin Sonatinası 

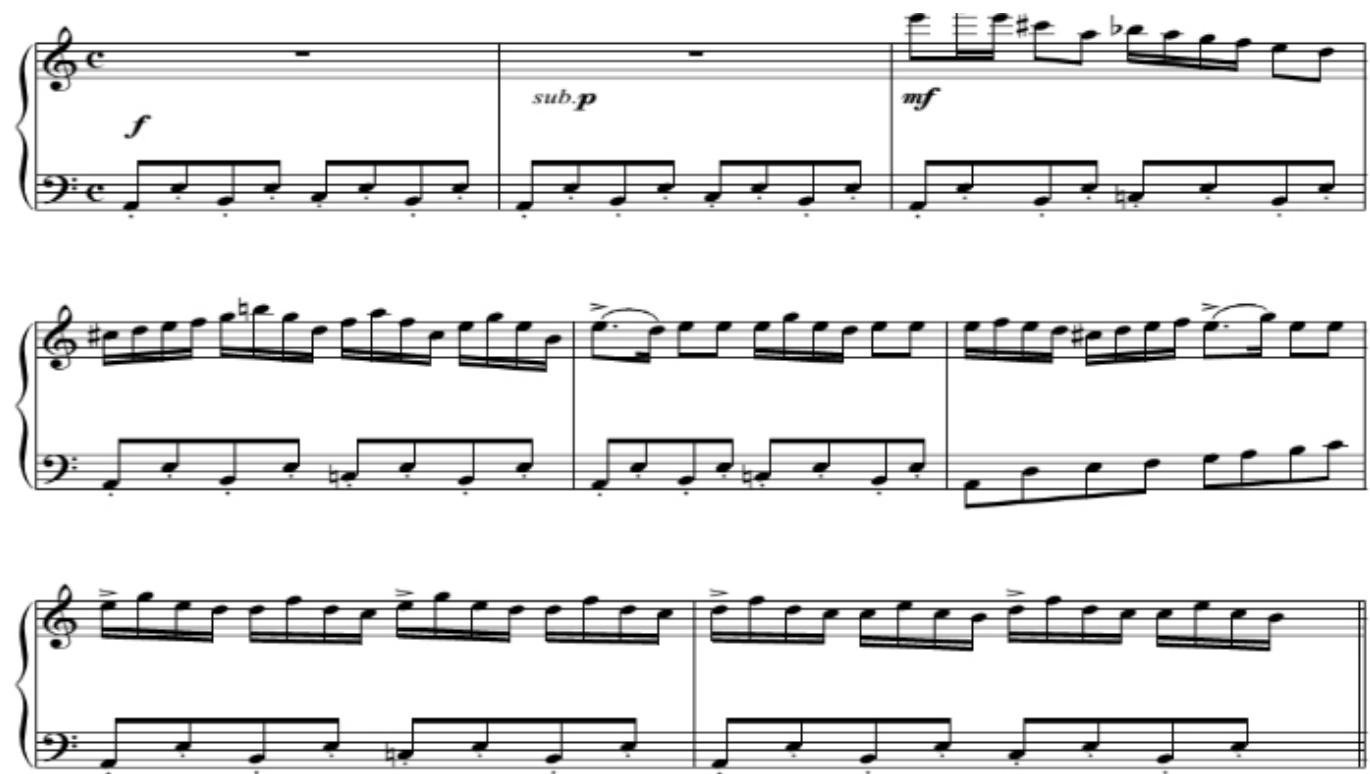

nümunesinde bestekarın prinsiplerini neoklassisist yazılmıș fortepiano eserinde hansı yolla tetbiq etdiyini göre bilerik. Sonatina, neolkassisist temayülün bariz nümunesi olsa da, ümumiyyetle, yaradıcılığının müxtelif merhelelerinde müxtelif üslub temayüllerine üz tutan, hem qedim, hem müasir bestekar yaradıcılığının vasitelerinden bacarıqla istifade eden Q.Qarayevin tutduğu senetkar mövqeyini ve rehber tutduğu senet prinsiplerini aşkar nümayiș etdirir. $\mathrm{Bu}$ da ondan ibaretdir ki, Q.Qarayev xalqımızın musiqi senetinin felsefesi ve estetikasının derin qatlarını duyur ve șifahi eneneli musiqimizin ifade vasitelerinden bacarıqla istifade ederek esl milli senetkar mövqeyinden çıxış edir, Avropanın bestekar yaradıcılığında teșekkül tapıb inkișaf etmiș bedii cereyanlar, müxtelif üslub temayülleri mecrasında formalașmış prinsipleri, bestekarlıq texnikasını özünexas terzde tetbiq edir. Bestekarın fortepiano
Sonatinasından görürük ki, o, neoklassisist üslub üçün seciyyevi olan, bu temayül çerçivesinde yer almıs ifade vasitelerini mehz milli zeminde, șifahi eneneli musiqi senetimizin derinliklerinden $a x ı b$ gelen prinsiplerle uzlașdıraraq tetbiq edir. Q.Qarayev, qeyri-milli zeminde meydana gelib intișar tapmıș bedii vasiteleri sadece öz fortepiano eserine köçürmür. Milli musiqi tefekkürüne ve ilk növbede muğam senetine xas olan janr, üslub, formayaranma, kompozisiya prinsiplerine derinden beled olan senetkar sanki bunların dünya bestekar yaradıcılığında teșekkül tapıb inkişaf etmiş ifade vasiteleri ile ortaq cehetlerini, kesișme nöqtelerini axtarıb taparaq, öz ferdi dest-xetti çerçivesinde üslub baxımından üzvi bir tamlıq teșkil eden gözel fortepiano nümuneleri yaradır.

Q.Qarayevin fortepiano yaradıcılığında Şerq-Qerb sintezini maraql ve olduqca orijinal bir «formatda» teqdim eden 
nümunelerden biri - «24 prelüd» silsilesinden XII h moll prelüdüdür. Bu, silsilenin ikinci defterini tamamlayan ve buradakı işıqlı obrazlardan bașlayaraq, derin facieviliye doğru yönelmiş dramaturji obraz inkișafını sona çatdıran prelüddür. Prelüdden alınan ilk teessürat bunun obrazlı mezmununun L.van Bethovenin ve F.Şopenin matem xarakteri ile așılanmıș fortepiano eserleri ile yaxınlığını sezmeye imkan verir. Eyni zamanda eserin intonasiya mezmununu, tematizmini, musiqi dilinin müxtelif cehetlerini diqqetle arașdırdıqda hemin facievi-matem obrazının tecessümünde bestekarın milli musiqi tefekkürü ve ilk növbede muğam senetinden gelen bedii ve kompozisiya üsullarına arxalandığını görürük.

Eserin tonallığ - h moll-dur. Lakin ele ilk xanelerden ostinat șekilde basda verilmiş oktavaların fis mayeli «Segah» muğamının intonasiya materialı ile qohumluğu așkar olur: bu, hemin muğamın mayesi etrafında eyniadlı lad-meqamın V ve II pillelerinin kömeyile dolanan seciyyevi intonasiyadır ki, bestekar bunu $\mathrm{h}$ moll-un dominantası etrafında dolanma șeklinde teqdim etmişdir. Basda oktavaların triollarla geden hereketi sanki ağır matem yürüșünü tesvir edir. Basların bu minvalla 4 xane seslenmesinin ardınca prelüdiyanın başlıca mövzusu yer alır. Bu mövzu ilk növbede qeyri-müntezem ritmik qurulușu ile diqqeti celb edir; artıq mövzunun teqdimatı ve ilkin inkișaf merhelesinde bunun teșekkül ve açılıș prosesinin muğam tematizmine xas olan terzde getdiyi belli olur. Bele ki, mövzu sanki olduqca ifadeli ve tesirli seslenen intonasiyanın daxilinden tedricen yaranıb inkişaf edir ve buradakı inkişaf da muğamdakı intonasiya inkișafını xatırladan üsullarla, varinat-sekvent yolla gedir.

Muğamla «qohumluq» melodik xettin getdikce daha yüksek registrleri ehate etmesinde, aramlı yükselișinde de öz eksini tapmıșdır. Hemçinin, burada ostinat bas ile musiqi toxumasının bașlıca mövzunu aparan hissesi arasında ritmik cehetden hemahengliyin olmaması, sabit, deyișilmez bas ile serbest ritmik qurulușlu melodiyanın birge seslenmesinde muğam senetinde geniș yer almış zerb-muğamların esas prinsipinin - ritmik cehetden müntezem, deqiq instrumental müșayiet fonunda qeyri-müntezem ritmikalı melodiyanın (vokal) seslenmesi prinsipinin tecessümünü göre bilerik. Belelikle, XII fortepiano prelüdünün tekce bașlanğıc fraqmentini nezerden keçirdikde, burada hem fakturada bas ile melodiyanın qarșılıqlı münasibetinde, hem intonasiya mezmununda, hem melodiyanın reçitativdeklamasiya düzümünde, hem mövzunun teșekkülü ve ilkin inkișaf merhelesinde bilavasite muğam senetinden ireli gelen prinsiplerin tamamile yeni müstevide ve yeni kontekstde, müasir yazı texnikası üsulları ile tecessüm etdirildiyini görürük.

Q.Qarayevin neoklassisist üslub mecrasında muğam prinsiplerini tezahür etdiren fortepiano eserleri sırasında onun prelüdleri xüsusi yer tutr. Söhbet bestekarın «24 prelüd» silsilesinin dördüncü defterinde cemleșen, neoklassisist üslubda yazdığı prelüdlerinden gedir.

«24 prelüd» silsilesinin sonuncu defterinde Q.Qarayevin polifoniyaya meyilli olması ve polifonist kimi yüksek senetkarlığı özünün parlaq ifadesini tapmıșdır. 
Q.Qarayev prelüdlerinin dördüncü defteri bestekarın neoklassisist meyillerini, onun qedim dövr musiqisinin janr ve formalarını yeni kompozisiya üsulları, yeni yazı texnikası vasitelerile, eyni zamanda milli musiqi yaradıcılığından gelen prinsiplerle üzvi suretde sintezleșdirmesinin parlaq nümunesidir.

Q.Qarayev silsilesinin son defterine daxil olan altı prelüdde bestekar barokko dövrünün janr ve formalarına müraciet ederek bunların tefsirini hem XX esr senetkarı mövqeyinden, hem Azerbaycan bestekarı olaraq, milli zemine dayaqlanan bir müellif kimi teqdim edir. Bestekar prelüdler qisminde riçerkar, passakalya, fuqa, invensiya kimi qedim nümuneleri yaratmıșdır. Sadaladığımız nümunelerin adlarından melum olur $\mathrm{ki}$, Q.Qarayev burada polifonik musiqinin janr ve formalarına geniș yer vermiş ve özünün polfonist meharetini bir daha parlaq nümayiș etdirmișdir. Bestekarın prelüdlerinin zirvesi hesab edile bilen bu defterde müellif polifonik janr ve formalardan, polifonik inkișaf üsullarından geniș istifade edir ve en deyerlisi budur ki, bunları muğama xas olan materialın teqdimatı ve inkișafı prinsipleri ile ele meharetle qovușdurur ki, yalnız Qarayeve xas olan dest-xettin bariz nümunesini görürük. Bestekar, özünün fortepiano eserlerinde de hem orta esr polifonistlerinin, hem de XX esrde polifoniyanın inkișafında mühüm rol oynamıss senetkarların nailiyyetlerini milli musiqi tefekkürü zemininde bacarıqla sintezleșdirerek, bunları yeni bedii keyfiyyetde teqdim etmişdir. Burada bir daha i.S.Baxın yaradıcılığını xatırlamalı oluruq, bele ki, Q.Qarayev öz müellimi D.Şostakoviç vasitesile dahi alman senetkarının yaradıcılıq üslubuna xas olan cehetleri derinden menimsemiș ve yeni müstevide tecessüm etdirmișdir. Hemçinin burada XX esrde polifonik musiqinin janr ve formalarının inkișafında müstesna rol oynamış diger bir alman bestekarı - P.Hindemitin de tesirini qeyd etmeliyik.

Q.Qarayev terefinden qedim formaların qanunauyğunluqlarının muğamı formalașdıran prinsiplerle üzvi suretde birleșdirilmesi nümunelerinden biri kimi «24 prelüd» silsilesinin dördüncü defterinden son nümuneni - 22 saylıb moll prelüdünü nezerden keçire bilerik.

B moll prelüdü Q.Qarayev terefinden passakalya kimi qedim polifonik nümune çerçivesinde muğama xas olan ifade üsulları ve formayaranması pinsiplerinin nece qovușdurulduğu barede tesevvür yaradır. Bestekar burada passakalyaya xas olan, tarixen bu janr çerçivesinde möhkemlenmiș olan facievi mezmunu böyük senetkarlıqla tecessüm etdirmeye nail olmuş, fortepiano miniatüründe facieviliyi yüksek bedii seviyyede eks etdirmișdir.

Q.Qarayev qedim polifonik janr olan passakalya ile milli musiqimizin klassik nümunesi olan muğam arasındakı ümumiliyi, bunların ortaq xüsusiyyetlere malik olduğunu senetkar duyumu ile sezerek ilk baxıșda bir-birinden böyük zaman ve mekanla ayrılan bu iki mükemmel qurumun mezmunu ve obrazlar alemini seciyyelendiren ve bunun ifadesini «reallașdıran» ortaq formayaranmaprinsipini-improvizasiyalıvariantlı prinsipi üze çıxarmıș ve bunun esasında esl milli nümune yaratmıșdır. Şübhesiz ki, bu ortaq prinsip birbirinden uzaq olan passakalya ve muğam janrlarında obrazlı mezmunun tipindeki ümumilikden ireli gelir. Müeyyen obrazın 
tedricen davam eden aramlı inkișafı her iki janr üçün seciyyevidir. Muğamda da, passakalyada da bașlıca qayenin merhelelerle inkișafını müșahide edirik. Yuxarıda vurğuladığımız, muğam kompozisiyasını seciyyelendiren prinsip - intonasiya inkișafında improvize elementinin olması șeraitinde muğamın formasında vehdeti temin eden, aparıcı rol oynayan «maye» mefhumu burada helledici rol oynamıșdır. Q.Qarayev, passakalya daxilinde hemin maye prinsipini yaradıcılıqla tetbiq ederek sanki bunu șaquli-polifonik «formata» keçirmișdir. Ostinat polifonik «lay» teșkil eden mövzu burada daim tekrarlanan, sabitlik funksiyasını qoruyub saxlayan ünsür kimi çıxıș edir.

B moll prelüdünde muğama xas olan sanki «spiralvari» inkișaf, yeni ümumi prosesde eniș-yoxușların olmasına baxmayaraq, tedricen yükselmekde davameden inkișafı göre bilerik. Prelüdün kulminasiya nöqtesinde bu intonasiya ve dinamik yükselișin son hedde çatdığı zaman oktava sessirasından kenara çıxması diqqeti celb edir.

\section{Prelüdde passakalyanın ostinat mövzusunun özünün intonasiya mezmunu-mahiyyetce deyișdirilmiș muğam menșeli intonasiyalardan qurulmușdur. Tamamile bașqa bir lad- harmonik mühite yerleșdirilmesine baxmayaraq, bu materialın muğamın intonasiya potensialından töremiș dolanma seciyyeli özeklerden ibaret olması așkardır.}

Prelüdün lad-meqam qurulușu da mürekkebliyi ile seçilir. Passakalyanın mövzusu șur intonasiyaları ile așılanmıșdır; burada V pillenin yarım ton alçaldılması Q.Qarayevin șur meqamına istinad eden melodiyaları üçün seciyyevi hesab edile biler - meselen, bestekarın «Leyli ve Mecnun» simfonik poemasında Giriș mövzusu da hemin boyalarla așılanmıșdır. Buradakı «fes» tonunu prelüdün esas tonallığı olan $b$ moll mövqeyinden nezerden keçirsek, DDVIIun esas tonu olduğunu görerik. Maraqlıdır ki, mövzuda diger istinad perdesi dominanta pillesi olan «f» de aydın qabardılır. Belelikle, muğamda müeyyen mesafede özünü büruze verdiyine göre heç bir daxili ziddiyyet yaratmayan bele qovușuqlar passakalyada sanki bir yerde cemleșmiș halda verilir ki, bu da melodiyanın sonrakı polifonik inkișafı üçün müeyyen «enerji toplamasını» temin edir.

Belelikle, XXII saylı fortepiano prelüdünde bestekar passakalyanın tefsirini teqdim ederken bunun muğamla temas nöqtelerini, mezmun ve forma seviyyesinde bütün kesișme meqamlarını taparaq, senetkarlıqla tetbiq etmișdir.

\section{Sonuç}

Q.Qarayevin polifonik eserlerinde șifahi eneneleri musiqiden gelen prinsiplerin tetbiqinden danışarken daha bir mühüm ceheti diqqete çatdırmalıyıq ki, bu da bestekarın istifade etdiyi ostinato prinsipidir. Şübhesiz ki, yuxarıda tehlil etdiyimiz polifonik musiqi nümunelerinde, fuqa ve passakalyada ostinato prinsipi mühüm formayaradıcı prinsip kimi fealiyyet gösterir. Yeni bu, adlarını çekdiyimiz polifonik forma ve janr üçün «doğma» prinsip kimi artıq möhkemlenmișdir. Lakin muğamdakı formayaranma prinsiplerini, muğam kompozisiyasındakı dramaturji inkişafı arașdırdıqda görürük ki, burada da 
ostinato prinsipi olduqca qabarıq șekilde özünü büruze verir.

Muğamdakı inkișaf prosesinin dramaturji prinsipi burada esas rol oynayan maye mefhumunun mütemadi olaraq «ayaq", yaxud, Avropa musiqisine aid terminle ifade etsek, kadensiya șeklinde qayıdıb seslenmesi burada ostinato prinsipinin müstesna rolunu üze çıxarmıș olur. Her bir muğamda forma-prosesin idare edilmesinde ve ostinato prinsipinin «işlemesinde» mühüm rol oynayan ayaq fenomeni eslinde hemin muğamın esas qayesinin ifadesi olan bașlıca mövzunun variantl, yeni bunun kompozisiya boyu tamhüquqlu bir temsilçisi funksiyasını daşıyır. Müntezem olaraq qayıdıb seslenen, muğamdakı intonasiya inkișafı prosesini sanki tenzimleyerek, esas qayeden her bir uzaqlașmanın «kompensasiyasını» ödeyen ve esas fikri, ideyanı sanki mütemadi olaraq tesdiqleyen bu «ayaq»lar muğamdakı ostinato prinsipinin bariz nümunesidir. Muğam tedqiqatçıları bu barede konkret müddealar ireli sürmüșler. Bunlardan birini sitat șeklinde diqqete çatdırmaqla kifayetlene bilerik: «Muğamdakı tezad kadensiyanın bunu ehate eden amillerle qarșılıqlı münasibetinde cemleșmișdir ve tezis-antitezis münasibeti kimi müeyyen edile biler. Mayeden her bir uzaqlașma buradakı merkezi ideyanın daha derinden açılmasına istiqametlendirilmișdir: zirveye doğru gelen yoldakı çoxmerheleli, fazalı inkișafda atılan her bir addım öz yolunda «ayaq»la rastlașaraq, heqiqeten de sanki «ayaq saxlayır» ve bunun ardınca yeni merhele gelir $\mathrm{ki}$, bu da yeniden hemin ayaq-kadensiya terefinden nezaretde saxlanılır. Ayaq mefhumu intonasiya mezmunu etibarile muğamın esas mövzusundan töreme olduğuna göre... bunun diger amillerle münasibeti «mövzu-qeyri mövzu» kimi qebul edilir. Mehz bu daxili tezad, mövzu ile «qeyrimövzunun», köhne ile yeninin, tezisle antitezisin «mübahisesi» forma-prosesin esas hereketverici qüvvesi kimi fealiyyet gösterir...»(Hesenova, 2011, s.112113). Buradan aydın olur ki, Q.Qarayev polifonik janr ve formalara müraciet eden zaman burada mühüm konstruktiv funksiyanı yerine yetiren ostinatlığın da hemin janr ve formaların muğam ile çarpazlașdığı bir meqam olduğunu sezmiş ve bu xüsusiyyetden istifade ederek, polifoniyanın bütün qanunlarını gözleyen, eyni zamanda milli musiqi tefekkürünün ve ilk növbede muğam senetinin de esasl prinsiplerine uyğunluğu eyani nümayiş etdiren eserler yaratmışdır. Ü.İmanova Q.Qarayevin klassisizme müracietinin sebeblerini arașdıraraq, haqlı olaraq bele neticeye gelir ki, bestekar üçün helledici amil «obyektiv ve subyektiv, ekspressiv ve rasional, duyğulu ve intellektual bașlanğıcın tarazlașmasıdır. Qarayevin Azerbaycan musiqisine xas olan ümumileșmiș felsefilik (muğam), heqiqetin obyektiv-epik inikası (aşıq medeniyyeti), bedii tenasübün mükemmel hissiyatı qaytarmaq metodu klassik kompozisiya formalarının musiqiemosional aleminin "cilovlanmasına» esaslanır» (İmanova, 1990, s.11). Belelikle, Q.Qarayevin fortepiano üçün yaratdığı eserler nümunesinde milli musiqi tefekkürü prinsiplerinin neoklassisizmüslubuçerçivesinde istifade edilen vasitelerle üzvi qovușuğunun elde edildiyini görürük. Bestekarın polifonik eserlerinde ise muğam tefekkürünün qanunauyğunluqları artıq eyni vaxtda hem keçmiş ve müasir dövrün polifonik yazı üslubu, hem de on iki tonlu xromatik tonallıq «mühitinde» tezahür ederek müellifin bu, son derece ferqli sistemlerin kesișme nöqtesini tapması sayesinde 
elde etdiyi yeni bedii keyfiyyetin bariz nümunesi kimi qiymetlendirilir.

\section{Kaynaklar}

Babaev E.A. Azerbaycan destgahının ritmi. Bakü: İshyg, 1990, $116 \mathrm{~s}$.

Hesenova Ș. XX esr Azerbaycan musiqisi: enene ve müasirlik. B., Apostrof, yayıncılık ve Baskı, 2011, 304 s.

Ibrahimova S.M. Fortepianonun tarixi ve onun dünya musiqi medeniyyetinin inkișafında rolu. Metodik vesait. Bakı, 2011

Qara Qarayev telebelerinin xatiresinde (tertibçi-redaktor N. efiyeva). B.: ŞerqQerb, 2009

Qafarova Z. Bestekarlarımızın portreti. Bakı: Azerneșr, $1992.31 \mathrm{s.}$

Makhmudova Sh.G. Mugamda dramatik sürecin taşıyıcısı olarak tema. Özet dis ... cand. Sanat Tarihi. B .: 1994, 20 s.

Imanova U.I. XX yüzyılın klasisizmi ve Kara Karaev // Yazarın özeti. dis ... cand. sanatlar. Tașkent, 1990, 23 s. 


\section{Mugam principles used in Gara Garayev's piano works in the east-west}

\section{Extended Abstract}

The manifestation of East-West synthesis in the field of music culture in itself covers a wide range of valuable and complex problems. When we look at the historical development of the art of music, which we have defined for centuries as the "Eastern" and "Western" musical culture, we can see that their interrelationships have a very ancient history and are manifested in many ways. The problems we examine in this study are specifically related to the work of national composers of the twentieth century and piano music, which is one of its important branches. The piano music of Azerbaijani composers includes a crossroads of different musical traditions and sources belonging to the East and the West.

At the same time, one of the main factors in the formation of piano music is the attachment to national music. However, Azerbaijani composers are never satisfied with this situation, they appeal to different trends and tendencies of European music, and widely use their means of expression. Thus, the factor of nationality is gradually deepens, and as a result, the style of piano music is undergoing a broad evolution. According to national principles, the new features of European music were "diffused" and took a new form of a unique unity and interesting results of a new quality emerged.That is, as a result of the intersection of different musical cultures, a completely new artistic quality is obtained. It finds its interesting, "multicultural" solution not only in the adaptation of the genre but also in the style. Azerbaijani composers are examples of the principles of the East, represented in the oral traditional national music, belonging to the West, neo-romanticism, neoclassicism, neo folklorism, widespread dodecaphonic writing techniques, aleatoric, sonorities, etc. They have proved the inexhaustibility of the possibilities of integration, even with the works they have created as a result of the synthesis of tradition and modernity.

The national composer's creativity is combined with the features of our traditional oral music through the artistic and technical means of modern music, new methods of composition, as well as folklore, neo-folklorism, neoclassicism, postmodernism, the latest trends, and styles. It is a manifestation of a problem defined as Western synthesis.

At various stages of the development of the piano creativity of Azerbaijani composers, there is a constant interest in new artistic trends, a tendency to renew the means of musical expression. In the first half of the twentieth century, national traditions in Azerbaijani piano music, including the principles flowing from mugham, along with Romanticism and Impressionism, were embedded in the work of European composers. One of them was the tendency of neoclassicism, which was associated with the name of G.Garayev and later found its brilliant manifestation in other areas of the national composer's work. When speaking about the tendency of neoclassicism in the piano work of Azerbaijani composers, we need to briefly mention the main features that characterize this style.

Piano works which are involved the neoclassicist style of G. Garayev that are typical for this indication, we see that the period of these people classicism genre and the revival of ancient music composition aspects of the twentieth century using enrichment, which applies the ancient music of the twentieth-century music genres, forms, manifests itself in the combination of language elements. The originality of neoclassicism in Garayev's work lies in the fact that the characteristic features of this stylistic trend, which is widespread in the music of the twentieth century, are important styles of national musical thinking and, above all, the art of mugham. In the piano works written by G.Garayev in the neoclassical style, the principles of mugham are completely obvious at the level of the organization of the material, the form of the music, the texture, and, in particular, the melody. Thus, in the example of G.Garayev's works for piano, we see the organic combination of the principles of national musical thinking with the means used in the neoclassical style. 
In the composer's polyphonic works, the conformity to the law of mugham thinking is already manifested at the same time in the "environment" of the author's "polyphonic writing style of the past and the present, as well as in the" environment "of the author's twelve-tone chromatic tonality evaluated as.

Keywords

gara garayev, composer, piano, East-West, music, work, analysis 